\title{
Critical success factors for eLearning in Saudi Arabian universities
}

\section{Introduction}

The concept of eLearning emerged to reflect the use of technology in the learning process. In universities, eLearning can be applied to deliver learning opportunities and resources to both oncampus and off-campus distance learning students, and is particularly beneficial in settings in which students may be geographically scattered. Due to the differences in the implementations of eLearning in different settings and its evolution over time, there are many definitions of eLearning. Amongst these, the definition offered by Sangrà, Vlachopoulos, and Cabrera (2012) has been widely accepted: "eLearning is an approach to teaching and learning, representing all or part of the educational model applied, that is based on the use of electronic media and devices as tools for improving access to training, communication and interaction and that facilitates the adoption of new ways of understanding and developing learning” (p.152).

Despite the huge investment in eLearning systems in both developed and developing countries, a low level of uptake of these systems by learners is common. Many researchers have sought to contribute to solving this issue by identifying the most important factors influencing adoption and use, otherwise referred to as critical success factors. Some studies have focused on a specific type of factor, (e.g. technical), but those that acknowledge that there are a wide range of different factors (e.g. learner characteristics, training, technical infrastructure) at work are of particular interest. However, most of these studies use surveys with students to explore critical success factors (e.g. Selim, 2007; Mosakhani and Jamporazmey 2010; Caporarello and Sarchioni, 2014), and a few have explored the views of ICT experts (e.g. Bhuasiri et al., 2012).

This study uses as its context eLearning in Saudi Arabia. Saudi Arabia is a large country with a significant and growing higher education system (Aljubaili, 2014) The Saudi government has been proactive in supporting the development of eLearning for both students on traditional courses and for those engaged in distance learning courses (Al-Dosari, 2011). The National Center for ELearning and Distance Learning (NCDEL) is prominent amongst similar centres in other parts 
of the Middle East and the Arab World, and has been pro-active in promoting and supporting the adoption of e-Learning in academic institutions. Whilst there is a growing literature on e-Learning projects and on the effect of e-Learning on student performance in Saudi Arabia (Al-Asmari and Khan, 2014), only three studies have attempted to identify the critical success factors for eLearning in universities in Saudi Arabia (Fryan and Stergioulas, 2012; AlTameem, 2005; Alhomod and Alshafi, 2012). In addition, most of the prior studies on e-Learning success have focused on the opinions of students and academic staff; only Hassanzadeh et al. (2012) and Bhuasiri et al. (2012) investigate the roles of eLearning experts.

Hence, the aim of this article is to offer further insights into the CSF's for eLearning, from the perspective of eLearning managers and with reference to the context of Saudi Arabia.

The next section elaborates further on initiatives for promoting eLearning in Saudi Arabia. This is followed by a literature review that summarises previous research on the CSF's associated with eLearning. Next, the research methodology adopted is outlined. The findings section includes profiles of the eLearning initiatives of the participating universities, and comments on CSF's for eLearning and their relative importance. Finally, the contribution of this research is summarized and recommendations for practice and further research are offered.

\section{Research Context: eLearning in Saudi Arabia}

The establishment of the National Centre of ELearning and Distance Learning (NCEDL) in 2005 by the Ministry of Higher Education in Saudi Arabia signaled the shift toward the embedding of eLearning in the Saudi educational system. The NCEDL encourages Saudi universities and helps them in their efforts to adopt and implement their eLearning systems. It also supports the digitalization the print resources such as books, and other learning resources (Al-Dosari, 2011).

In pursuit of its mission, the NCEDL has a general remit regarding the transfer of international knowledge and experiences in developing and implementing eLearning systems in the Saudi educational system. In addition, the Centre aims to expand its scope to beyond Saudi borders by making eLearning resources and technologies available for non-Saudi learners (Abaalhassan, 2007) and thereby to provide leadership in eLearning in the Middle East and the Arab World. 
The NCEDL has been involved in a number of projects. One of the first such projects was the development of the Jusur Learning Management System (LMS), which is now used by many governmentally funded universities (public). Another project was the development of The

Learning Portal, which makes online learning materials available for students remotely, whilst also providing teachers with teaching skills enhancement tools and learning materials. In addition, the NCEDL offers an eLearning Award for excellence, which is an award that is given to creative individuals and institutes in the field of eLearning (NCEDL, 2015). Alongside these projects, the NCEDL it has formed partnerships with about 42 educational institutions, most of which are universities (NCEDL, 2015).

Universities have responded positively to government and NCEDL initiatives and many are proactively embedding e-Learning in their educational processes. Two of the largest universities in Saudi Arabia, King Saud University (KSU), and King Abdul Aziz University (KAU)), are gradually converting their conventional educational curricula to embrace e-Learning. These universities and others, have also put in place new departments and deanships that are dedicated to introducing and enhancing e-Learning based educational systems.(Al-Asmari,2014). For example, King Fahad University of Petroleum and Minerals (KFUPM) has a dedicated eLearning centre which cooperates with the academic affairs deanship in the university to offer around 80 online courses in both English and Arabic through an OpenCourseWare Consortium. King Abdul Aziz University (KAU) uses its Learning Management System (LMS) to offer academic support for first and second year students, including access to a wide range of online academic resources including about 16000 eBooks (Al-Asmari, 2014).

The Saudi government also encourages eLearning through the allocation of $\$ 125 \mathrm{~m}$ for the development and integration of eLearning artefacts in Saudi educational institutions.

\section{Literature Review}

\subsection{Definitions of Critical success factors}

Research into the influencers of eLearning makes use of the concept of critical success factors (CSF's). The concept of critical success factors originates in the organizational strategy literature, 
and is defined, for instance by Bruno and Leidecker (1984: 24) as "characteristics, conditions or variables that, when properly sustained, maintained, or managed, can have a significant impact on the success of a firm competing in a particular industry". In addition, CSFs are also defined as "those factors addressed significantly to improve project implementation chances" (cited in Amberg, Fischl and Wiener, 2005). Cheawjindakarn, Suwannatthachote, and Theeraroungchaisri (2012) have described CSFs in the area of Online Distance Learning, which can be considered as a sub-field of eLearning, as 'the areas that must be critically taken care of if institutions that needs success'.

\subsection{Critical success factors in eLearning}

There is a relatively extensive literature on the critical success factors for eLearning, based on studies conducted in various parts of the world, but few have been conducted in the Middle East. These studies typically identify a number of categories of factors that might influence the acceptance and success of eLearning. Typical categories that are re-iterated in many studies, and that are hence used in this study are: student characteristics, instructor characteristics, learning environment, instructional design, and support. Also, each of these categories involves a number of specific factors. For example, in this research, and drawing on the literature, within the student characteristics factor, we include: pace of learning, commitment, attitude, motivation, knowledge of computer systems, and demographics. However, beyond this there are considerable variations between individual studies, in terms of the number of categories and the specific factors within those categories. Table 1 presents a summary of some of the key studies on CSF's for eLearning. Table 1 shows that whilst some authors divide eLearning CSFs into four different categories (e.g. Selim, 2007), other authors expand this list to include ten categories (Bhuasiri et 2012). Table 1 also shows that studies have been conducted over a period of time and in different countries, and take into account the views of different groups of stakeholders, including eLearning experts, students and academic staff. 


\begin{tabular}{|c|c|c|c|c|c|c|c|}
\hline Article & $\begin{array}{l}\text { Selim } \\
(2007)\end{array}$ & $\begin{array}{c}\text { Menchacaa } \\
\text { and } \\
\text { Abate } \\
\text { Bekeleb } \\
\text { (2008) } \\
\end{array}$ & $\begin{array}{c}\text { Mosakhani } \\
\text { and } \\
\text { Jamporazmey } \\
\text { (2010) }\end{array}$ & $\begin{array}{l}\text { Hassanzadeh, } \\
\text { Kanaani, } \\
\text { And Elahi } \\
\text { (2012) }\end{array}$ & $\begin{array}{c}\text { Bhuasiri et al. } \\
\text { (2012) }\end{array}$ & $\begin{array}{c}\text { Caporarello } \\
\text { And Sarchioni } \\
(\mathbf{2 0 1 4 )}\end{array}$ & $\begin{array}{l}\text { Abdel-Gawad and } \\
\text { Woollard (2015) }\end{array}$ \\
\hline $\begin{array}{l}\text { Sample } \\
\text { members }\end{array}$ & Students & $\begin{array}{c}\text { Students } \\
\text { Faculty } \\
\text { members }\end{array}$ & Students & $\begin{array}{l}\text { eLearning } \\
\text { experts }\end{array}$ & $\begin{array}{l}\text { ICT experts } \\
\text { Faculty } \\
\text { members } \\
\end{array}$ & Students & $\begin{array}{c}\text { Technology } \\
\text { students and } \\
\text { lecturers }\end{array}$ \\
\hline Country & $\begin{array}{c}\text { United Arab } \\
\text { Emirates }\end{array}$ & USA & Iran & Iran & Thailand & Italy & Egypt. \\
\hline \multicolumn{8}{|l|}{ Factors category } \\
\hline $\begin{array}{l}\text { Instructor } \\
\text { Characteristics }\end{array}$ & $\mathrm{x}$ & $X$ & $\mathrm{x}$ & $\mathrm{x}$ & $\mathrm{x}$ & & $\mathrm{x}$ \\
\hline $\begin{array}{l}\text { Student } \\
\text { Characteristics }\end{array}$ & $\mathrm{x}$ & $\mathrm{X}$ & $\mathrm{x}$ & $\mathrm{x}$ & $\mathrm{x}$ & $\mathrm{x}$ & $\mathrm{x}$ \\
\hline $\begin{array}{l}\text { Information } \\
\text { Technology } \\
\end{array}$ & $\mathrm{x}$ & $X$ & $\mathrm{x}$ & $\mathrm{x}$ & $\mathrm{x}$ & $\mathrm{x}$ & $\mathrm{x}$ \\
\hline Support & $\mathrm{x}$ & & $\mathrm{x}$ & & $\mathrm{x}$ & $\mathrm{x}$ & $\mathrm{x}$ \\
\hline $\begin{array}{l}\text { Technology } \\
\text { Knowledge }\end{array}$ & & & $\mathrm{x}$ & & $\mathrm{x}$ & $\mathrm{x}$ & $\mathrm{x}$ \\
\hline Course & & $X$ & & $\mathrm{x}$ & $\mathrm{x}$ & $\mathrm{x}$ & \\
\hline $\begin{array}{l}\text { Instructional } \\
\text { Design }\end{array}$ & & $\mathrm{X}$ & $\mathrm{x}$ & $\mathrm{x}$ & & & $\mathrm{x}$ \\
\hline $\begin{array}{l}\text { eLearning } \\
\text { Environment }\end{array}$ & & & & & $\mathrm{x}$ & & $\mathrm{x}$ \\
\hline $\begin{array}{l}\text { Level of } \\
\text { Collaboration } \\
\end{array}$ & & & $\mathrm{x}$ & & $\mathrm{x}$ & $\mathrm{x}$ & $\mathrm{x}$ \\
\hline $\begin{array}{l}\text { Knowledge } \\
\text { Management } \\
\end{array}$ & & & $\mathrm{x}$ & & $\mathrm{x}$ & & \\
\hline
\end{tabular}

Table 1: ELearning CSFs categories used in some prior studies 
Table 1 shows that there are factors categories that are repeated by more authors than others. For example, students' characteristics, instructor characteristics, and information technology are almost agreed by all the authors listed in the table to be a CSF for eLearning, which indicated the importance of these categories. The main focus of the students' characteristics category are those characteristics which influence the eLearning project acceptance by students. Some of these characteristics include students' pace of learning, their level of commitment to and attitude towards eLearning, and their level of motivation (Selim, 2007; Mosakhani and Jamporazmey, 2010). Other student characteristics are their previous knowledge with computer systems in general, and their demographic characteristics (gender, age, level of academic programme, etc.) (Colley et al., 1994). On the other hand, several of the instructor characteristics can contribute to the success and acceptance of an eLearning system. Amongst these are instructors' attitude towards students, their teaching styles, their attitude towards and skills to use the available technologies, and their ability to motivate the students in general and to learn using an eLearning system in specific. Yet a third important category of factors is information technology; this category focuses on the general role of new technological innovations in the success of eLearning systems. Some of the less common mentioned categories of eLearning CSFs are eLearning environment and knowledge management.

Given the diversity of different studies, in seeking to distill a list of categories, and their specific factors a wide-ranging literature review was conducted. The findings from this are summarized in Table 2. Table 2 identifies the main groups of factors that emerge from this literature review, with their specific factors and the previous research that have identified or discussed these factors. The categories in Table 2 informed the design of the interviews used to interrogate viewed on the CSF's for eLearning in this study. 


\begin{tabular}{|c|c|c|}
\hline Category & Factor & Prior research \\
\hline \multirow{6}{*}{$\begin{array}{c}\text { Student } \\
\text { characteristics }\end{array}$} & Pace of learning & $\begin{array}{l}\text { Salmeron, (2009); Masrom et al., (2008); Leidner } \\
\text { and Jarvenpaa, (1993); Caporarello } \\
\text { And Sarchioni (2014) }\end{array}$ \\
\hline & Commitment & Colley et al., (1994) \\
\hline & Attitude & $\begin{array}{l}\text { Le Blanc and Wands, (2001); Caporarello } \\
\text { And Sarchioni (2014) }\end{array}$ \\
\hline & Motivation & Pawlowski, 2002; Salmeron, (2009) \\
\hline & $\begin{array}{l}\text { Knowledge of computer } \\
\text { systems }\end{array}$ & $\begin{array}{l}\text { Abdel-Gawad and Woollard (2015); Caporarello } \\
\text { And Sarchioni (2014) }\end{array}$ \\
\hline & Demographics & Colley et al. (1994) \\
\hline \multirow{5}{*}{$\begin{array}{c}\text { Instructor } \\
\text { characteristics }\end{array}$} & Attitude & Webster and Hackley (1997); \\
\hline & Flexibility & (Haynes et al., 1997) \\
\hline & $\begin{array}{l}\text { Knowledge of learning } \\
\text { technologies }\end{array}$ & Abdel-Gawad and Woollard (2015); \\
\hline & Teaching style & Abdel-Gawad and Woollard (2015); \\
\hline & $\begin{array}{l}\text { Efficacy in student } \\
\text { motivation }\end{array}$ & Haynes et al.(1997). \\
\hline \multirow{4}{*}{$\begin{array}{c}\text { Learning } \\
\text { Environment }\end{array}$} & $\begin{array}{l}\text { Learning Management } \\
\text { System (LMS) }\end{array}$ & $\begin{array}{l}\text { Selim (2005; 2007); Chantanarungpak } \\
\text { Huddlestone and Pike (2008) }\end{array}$ \\
\hline & Technical infrastructure & $\begin{array}{l}\text { Masrom, Zainon and Rahiman (2008); } \\
\text { Selim (2005) }\end{array}$ \\
\hline & Interactive learning & $\begin{array}{l}\text { McIntyre and Wolff (1998); Moore and Kearsley } \\
(2005) ;(\text { Selim, 2005). }\end{array}$ \\
\hline & Access and navigation & Allen and Seaman (2005); Penn State (2008) \\
\hline \multirow{5}{*}{$\begin{array}{l}\text { Instructional } \\
\text { Design }\end{array}$} & Objectives clarity & $\begin{array}{l}\text { Selim (2005); Mosakhani and Jamporazmey (2010) } \\
\text { Bhuasiri (2012) }\end{array}$ \\
\hline & Content quality & $\begin{array}{l}\text { Selim (2005); Mosakhani and Jamporazmey (2010) } \\
\text { Bhuasiri (2012). }\end{array}$ \\
\hline & Learning strategies & $\begin{array}{l}\text { Bacsich, Bastiaens and Bristow (2009); Abdel-Gawad } \\
\text { and Woollard (2015). }\end{array}$ \\
\hline & Learning psychology & $\begin{array}{l}\text { Pawlowski (2002); Bacsich, Bastiaens and Bristow, } \\
\text { (2009) }\end{array}$ \\
\hline & Assessment & Abdel-Gawad and Woollard (2015). \\
\hline \multirow{3}{*}{ Support } & Communication tools & $\begin{array}{l}\text { Salmeron (2009); Bhuasiri et al. (2012); Caporarello } \\
\text { And Sarchioni (2014) }\end{array}$ \\
\hline & Help desk availability & $\begin{array}{l}\text { Bacsich, Bastiaens and Bristow (2009); Puri (2012); } \\
\text { Caporarello And Sarchioni (2014) }\end{array}$ \\
\hline & Training & $\begin{array}{l}\text { Mosakhani and Jamporazmey (2010); Puri (2012) } \\
\text { Bacsich, Bastiaens and Bristow (2009); Caporarello } \\
\text { And Sarchioni (2014) }\end{array}$ \\
\hline
\end{tabular}

Table 2: Critical Success Factors for eLearning based on prior research 


\subsection{Prior research into ELearning CSFs in Saudi Arabia}

There are only a few studies that specifically explore eLearning CSFs in a Saudi context. The most comprehensive of these was conducted by Fryan and Stergioulas (2012) and aimed at identifying eLearning CSFs in Saudi academic institutions. On the basis of a literature review they identified 39 eLearning CSFs grouped into the four categories: individual, social, economic, and organizational/governmental factors. Through empirical research using interviews and questionnaires in five different Saudi universities and training centres, they found general agreement between the results of their literature review and their empirical data, although their empirical study identified an additional 13 eLearning CSFs to those found in the literature, whilst six other factors from the literature were found to be of no importance. In summary, Fryan and Stergioulas (2012) identified 52 different eLearning CSFs that are relevant to the Saudi context within the 4 categories found in the literature review. While Fryan and Stergioulas (2012)'s work is important, their study overlooks one major category that is evident in the literature, support, and their investigation of the important categories of student and instructor characteristics was limited. In addition, they made no attempt to evaluate the relative importance of the different factors.

Two studies that have been conducted on eLearning CSF's in Saudi Arabia both have limited scope, focusing on the technical and management aspects of the eLearning system, with little reference to learners, their teachers and learning processes. AlTameem (2013) in 2005, used a qualitative case-study-based approach to identify the classes of technical issues which can effect eLearning systems implementation. These issues are: reliability of the ICT infrastructure; system security; access (on-site and off-site); and, availability of IT support. Alhomod and Alshafi's (2012) study was slightly wider in its scope, but the focus remained on the technical staff perspective of eLearning CSFs. Conducted at King Saud University, the study identified the following CSF's, in the following order of importance: sufficient user training, organization commitment, management support, technical support, positive attitude of users, easy to use tools, sufficient training for engineers, sufficient eLearning initiatives, sufficient manpower, availability of information on the eLearning website, support from other departments. In addition, it is useful to also refer to the literature review by Al-Asmari and Khan (2014) that, rather than discussing success factors, considers obstacles. In a wide ranging review, they identify the following 
categories of obstacles to eLearning in Saudi Arabia: technical, material and financial, and organizational and administrative.

Overall, the paucity of studies on CSF's in eLearning in Saudi Arabia and the limitations of the existing studies, suggests that there is scope for further research, to explore not only the relevance of specific CSF's in Saudi Arabia, but also to comment on their relative importance and to provide more general insights into the reasons behind their importance. In addition, it would be useful to understand whether there is anything unique about the Saudi Arabian context that might impact on eLearning adoption and success.

\section{Research methodology}

The aim of this article is to offer further insights into the CSF's for eLearning, from the perspective of eLearning managers and with reference to the context of Saudi Arabia.

In order to achieve this aim, a qualitative approach was adopted, in order to achieve a deeper understanding of views on the factors that affect the success of eLearning in Saudi Arabia. In this first stage of a more extensive study, it was felt that the opinion of experts would be beneficial, and that it would be useful to involve participants from three different universities. These universities were Kind Saud University, Majmaah University, and Qassim University. These universities were selected because of their high level of commitment to e-Learning initiatives. Practical constraints relating to the willingness of staff to be interviewed, and travel convenience for the researcher, also influenced the choice of university. In addition, extending the study to three universities enabled exploration of any differences in perceptions of critical success factors that might derive from other differences between the three universities. All three of the universities take both male and female students.

Participants were selected on the basis of their roles in eLearning, but unlike earlier studies in Saudi Arabia (Alhomod and Alshafi, 2012; AlTameem, 2005), participants in this study had an academic background, with extensive experience of learning processes. They also hold pivotal strategic roles, and hence have high levels of expertise in relation to the implementation and use of eLearning in their universities and are located in three universities in Saudi Arabia where 
eLearning is well-established (Table 4).

\begin{tabular}{|c|c|c|c|c|}
\hline & Job role & University & $\begin{array}{c}\text { Years of } \\
\text { experiences }\end{array}$ & eLearning projects \\
\hline 1 & $\begin{array}{l}\text { Vice dean for } \\
\text { academic affairs, } \\
\text { Deanship of eLearning }\end{array}$ & \multirow{3}{*}{$\begin{array}{l}\text { King Saud } \\
\text { University }\end{array}$} & 5 & \multirow{3}{*}{$\begin{array}{l}\text { 1. Digital content improving tools. } \\
\text { 2. Learning management system. } \\
\text { 3. Virtual classrooms. } \\
\text { 4. Educational community system. } \\
\text { 5. Training management system. } \\
\text { 6. Mobile learning. } \\
\text { 7. SMS services. } \\
\text { 8. Saudi digital library. } \\
\text { 9. Reporting System. } \\
\text { 10. Instant Messaging (IM). } \\
\text { 11. Voice Authoring }\end{array}$} \\
\hline 2 & $\begin{array}{l}\text { Head of the eLearning } \\
\text { Program, Information } \\
\text { Science department. }\end{array}$ & & 9 & \\
\hline 3 & $\begin{array}{l}\text { Director of quality } \\
\text { assurance unit, } \\
\text { Deanship of } \\
\text { eLearning. }\end{array}$ & & 10 & \\
\hline 4 & $\begin{array}{l}\text { Vice dean of } \\
\text { eLearning. }\end{array}$ & \multirow[b]{2}{*}{$\begin{array}{l}\text { Majmaah } \\
\text { University }\end{array}$} & 5 & \multirow{2}{*}{$\begin{array}{l}\text { 1. Contribute to the implementation Desire2Learn } \\
\text { 2. Television production education. } \\
\text { 3. Development of virtual labs. } \\
\text { 4. E-content development. } \\
\text { 5. Training courses for faculty members. } \\
\text { 6. Technical support programme development. }\end{array}$} \\
\hline 5 & $\begin{array}{l}\text { Head of computer } \\
\text { science department }\end{array}$ & & 4 & \\
\hline 6 & $\begin{array}{l}\text { Vice dean for } \\
\text { academic affairs, } \\
\text { deanship of eLearning. }\end{array}$ & \multirow[b]{2}{*}{$\begin{array}{l}\text { Qassim } \\
\text { University }\end{array}$} & 10 & \multirow{2}{*}{$\begin{array}{l}\text { 1. Development of e-courses programme. } \\
\text { 2. Learning management system. } \\
\text { 3. Training courses for faculty members. } \\
\text { 4. Mobile learning. } \\
\text { 5. Virtual classrooms. } \\
\text { 6. The use of Facebook in education. } \\
\text { 7. The use of podcasts in education. } \\
\text { 5. Technical support programme development. }\end{array}$} \\
\hline 7 & $\begin{array}{l}\text { Head of computer } \\
\text { science department. }\end{array}$ & & 6 & \\
\hline
\end{tabular}

Table 3: Participants

Prior to conducting the interviews, desk research was conducted on the web sites of the participating universities, in order to develop a profile of the eLearning objectives, initiatives and systems at each of the universities. Interviews were chosen as the research method, since they offer the opportunity for discussion and the surfacing of unanticipated insights. Interviews were guided by a semi-structured interview schedule, which, based on previous research, identified the key groups of CSF's for eLearning, and the specific factors within those groups. Interviewees were 
first asked to rank the importance of the groups of CSF's (e.g. student characteristics) and then to rank the specific factors within the groups. They were also asked to discuss their rankings, and to comment further on the various CSF's.

With one exception, the interviews were conducted face-to-face in the participants' work place. For one interview where this was not possible, so the participant completed an e-mail interview. Before conducting the interviews, the researcher explained the purpose of both the project and more specifically that of the interview. The interviewees were made aware that their participation was not obligatory and that they could terminate the interview at any point. All interviewees were asked for permission to record their interview; for those who declined, the interviewer took notes. Interviews were transcribed and subjected to a thematic analysis. A qualitative thematic analysis has been described by Braun and Clarke (2006) as identifying, analysing and reporting patterns (themes) within data. It minimally organises and describes your data set in (rich) detail. However,

frequently it goes further than this, and interprets various aspects of the research topic. '(p.6). Thus, the researcher went through the transcripts and analyzed them looking for similarities in level of importance of the different eLearning CSFs, the reasoning behind giving a specific CSF a specific level of importance, and any other insights on CSF's.

\section{Findings}

\subsection{Profile of participating universities}

The universities which were selected are well known universities in Saudi Arabia. The following table summarizes basic information about each of these universities and their involvement with eLearning. All of these universities offer both on campus and off campus eLearning facilities. 


\begin{tabular}{|c|c|c|c|c|c|c|}
\hline University & $\begin{array}{l}\text { No. of } \\
\text { students }\end{array}$ & $\begin{array}{l}\text { Type of } \\
\text { students }\end{array}$ & $\begin{array}{l}\text { Implementation } \\
\text { of eLearning } \\
\text { from }\end{array}$ & LMS platform & $\begin{array}{c}\text { Mission statement regarding } \\
\text { eLearning }\end{array}$ & $\begin{array}{l}\text { Support \& } \\
\text { training }\end{array}$ \\
\hline $\begin{array}{l}\text { Majmaah } \\
\text { Univeristy }\end{array}$ & 24288 & $\begin{array}{l}\text { Undergraduate } \\
\text { and } \\
\text { postgraduate }\end{array}$ & 2013 & $\begin{array}{c}\text { Desire2Learn } \\
\text { http://el.mu.edu.sa/ }\end{array}$ & $\begin{array}{l}\text { Providing a learning environment } \\
\text { and advanced interactive } \\
\text { electronic training }\end{array}$ & Workshops \\
\hline $\begin{array}{l}\text { King Saud } \\
\text { University }\end{array}$ & 63098 & $\begin{array}{l}\text { Undergraduate } \\
\text { and } \\
\text { postgraduate }\end{array}$ & 2008 & $\begin{array}{c}\text { Blackboard } \\
\text { Learn } \\
\text { https://lms.ksu.edu.sa/ }\end{array}$ & $\begin{array}{l}\text { Increasing the quality of the } \\
\text { eLearning and improve its } \\
\text { outputs, and provide an electronic } \\
\text { environment that support the } \\
\text { performance of the faculty } \\
\text { members and students through } \\
\text { efficient using of eLearning } \\
\text { applications. }\end{array}$ & Workshops \\
\hline $\begin{array}{l}\text { Qassim } \\
\text { University }\end{array}$ & 52000 & $\begin{array}{l}\text { Undergraduate } \\
\text { and } \\
\text { postgraduate }\end{array}$ & 2013 & $\begin{array}{c}\text { Blackboard } \\
\text { Learn } \\
\text { https://qu.blackboard.com/ }\end{array}$ & $\begin{array}{l}\text { Providing integrated electronic } \\
\text { learning environment encouraging } \\
\text { learning supportive of the } \\
\text { performance, building a distinct } \\
\text { contents, and activation of } \\
\text { national and international } \\
\text { partnership in the field of } \\
\text { eLearning to contribute to the } \\
\text { sustainable development of } \\
\text { education in the kingdom. }\end{array}$ & Workshops \\
\hline
\end{tabular}

Table 4: Participating Universities 


\subsection{CSF's for eLearning}

\subsubsection{Introduction and category rankings}

This analysis presents the key findings from interviews conducted with seven key informants regarding the factors that they regarded as most important in influencing the success of eLearning in their universities. This section reports on the ranking of the categories of factors and the rationale for these rankings, and then reports in more detail on views on the individual factors. Throughout this analysis, comments focus on consensus, although the data is also interrogated for any patterns that suggest differentiation between the universities.

\begin{tabular}{|c|c|c|c|c|c|}
\hline Interviewee & $\begin{array}{c}\text { Student } \\
\text { characteristics }\end{array}$ & $\begin{array}{c}\text { Instructor } \\
\text { characteristics }\end{array}$ & $\begin{array}{c}\text { Learning } \\
\text { environment }\end{array}$ & $\begin{array}{c}\text { Instructional } \\
\text { Design }\end{array}$ & Support \\
\hline Q1 & 2 & 3 & 1 & 5 & 4 \\
\hline Q2 & 3 & 2 & 1 & 4 & 5 \\
\hline M1 & 2 & 1 & 4 & 3 & 5 \\
\hline M2 & 1 & 2 & 3 & 4 & 5 \\
\hline K1 & 1 & 2 & 4 & 3 & 5 \\
\hline K2 & 4 & 1 & 2 & 3 & 5 \\
\hline K3 & 1 & 2 & 3 & 5 & 4 \\
\hline Total: & 14 & 13 & 18 & 27 & 33 \\
\hline
\end{tabular}

Table 5: eLearning critical success factor categories rankings

Examining Table 5, specifically the total row, the categories are ranked from most to least important in the following order: instructor characteristics, student characteristics, learning environment, instructional design, and support. More specifically, instructor characteristics are ranked 1 or 2 by six of the seven interviewees, and student characteristics are ranked 1 or 2 by five of the seven interviewees. There is a little more variation on the relative ranking of the learning environment, but there is a general agreement that both instructional design and support are, relatively less important. The table also shows that two interviewees (from the same university) ranked learning environment as 1, whilst interviewees from both of the other two universities placed a mix of student characteristics and instructor characteristics as 1. However, examining the first two positions across all interviewees' rankings, there is some consensus that learning 
environment, instructor characteristics and student factors are pivotal to the success of eLearning environments.

\subsubsection{Rankings within category}

This section comments on at the rankings of individual CSF's as shown in Table 6 (Rankings of CSF's). It both comments on points of specific interest within the rankings, and also offers deeper insights on the basis of quotes from participants.

\section{Instructor characteristics}

Instructor related CSFs were selected as the most important category by most of the interviewees. Interestingly, there was a high level of consensus on the importance of the instructor's knowledge with the learning technologies in determining the success of eLearning. In particular, the three interviewees from K3 University have all selected this factor as the most important. Supporting this selection, M2 explains:

'Having a deeper knowledge of learning technologies will allow the instructor to search further and deeper for more technologies that he can use in the education processes'.

Teaching style and a positive attitude are in second and third place, respectively, although there is more variability in the importance ranking of these factors. Comments on teaching style include:

'Having a variety of teaching styles helps the success of the educational process in general and helps the success of the eLearning system as well' (M1)

'It is an essential part of the educational process, which can include other parts such as instructors' guidance and training packages. Choosing the suitable teaching style is essential for the success of learning' (K1).

'The teaching styles must ... suit the learning through the eLearning system' (M2) 


\begin{tabular}{|c|c|c|c|c|c|c|c|c|c|c|c|c|c|c|c|c|c|c|c|c|c|c|c|}
\hline \multirow[b]{3}{*}{ Interviewee } & \multicolumn{23}{|c|}{ Factors } \\
\hline & \multicolumn{6}{|c|}{ Student characteristics } & \multicolumn{5}{|c|}{$\begin{array}{c}\text { Instructor } \\
\text { characteristics }\end{array}$} & \multicolumn{4}{|c|}{ Learning environment } & \multicolumn{5}{|c|}{ Instructional Design } & \multicolumn{3}{|c|}{ Support } \\
\hline & 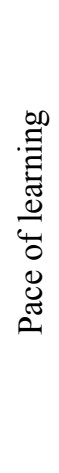 & 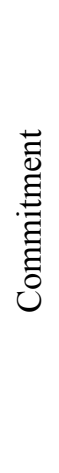 & 总 & 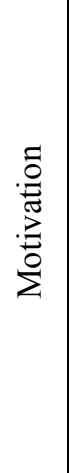 & 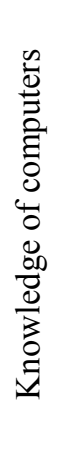 & 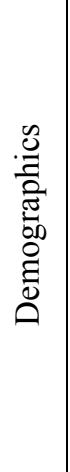 & $\begin{array}{l}\text { 莨 } \\
\text { 至 }\end{array}$ & 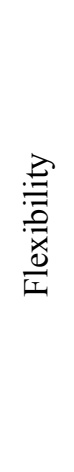 & 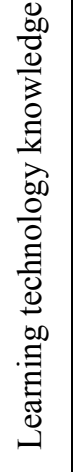 & 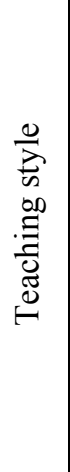 & 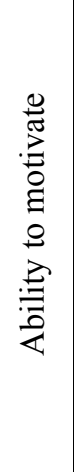 & 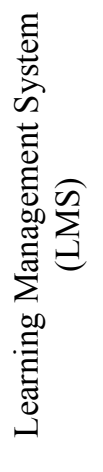 & 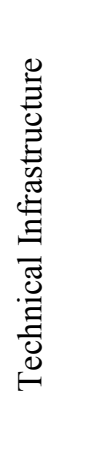 & 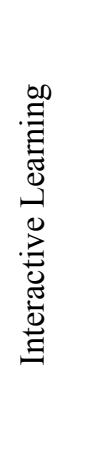 & 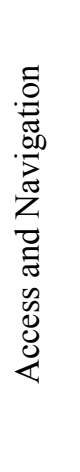 & 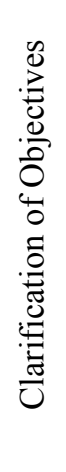 & 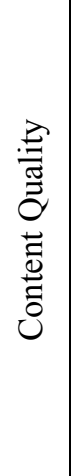 & 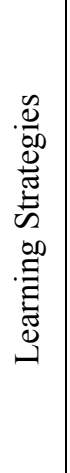 & 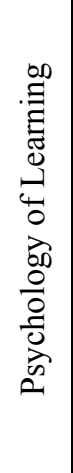 & 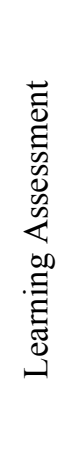 & 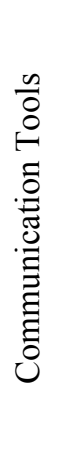 & 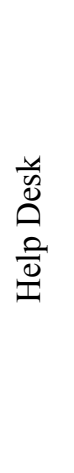 & 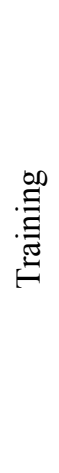 \\
\hline Q1 & 4 & 5 & 3 & 6 & 2 & 1 & 4 & 1 & 2 & 3 & 5 & 4 & 2 & 3 & 1 & 1 & 2 & 3 & 5 & 4 & 1 & 3 & 2 \\
\hline Q2 & 2 & 1 & 5 & 4 & 3 & 6 & 2 & 4 & 1 & 5 & 3 & 2 & 1 & 4 & 3 & 1 & 2 & 3 & 4 & 5 & 1 & 2 & 3 \\
\hline M1 & 4 & 1 & 3 & 5 & 2 & 6 & 3 & 5 & 1 & 2 & 4 & 2 & 3 & 4 & 1 & 1 & 3 & 4 & 2 & 5 & 2 & 3 & 1 \\
\hline M2 & 2 & 4 & 5 & 1 & 3 & 6 & 4 & 5 & 2 & 1 & 3 & 2 & 1 & 3 & 4 & 2 & 1 & 3 & 5 & 4 & 2 & 3 & 1 \\
\hline K1 & 4 & 5 & 1 & 2 & 3 & 6 & 2 & 5 & 1 & 3 & 4 & 1 & 2 & 4 & 3 & 1 & 2 & 3 & 5 & 4 & 3 & 1 & 2 \\
\hline K2 & 5 & 6 & 3 & 4 & 1 & 2 & 3 & 2 & 1 & 4 & 5 & 3 & 2 & 1 & 4 & 1 & 3 & 2 & 4 & 5 & 2 & 3 & 1 \\
\hline $\mathbf{K 3}$ & 6 & 3 & 2 & 5 & 4 & 1 & 4 & 5 & 1 & 2 & 3 & 2 & 1 & 4 & 3 & 5 & 3 & 1 & 2 & 4 & 3 & 2 & 1 \\
\hline Total & 27 & 25 & 22 & 27 & 18 & 28 & 22 & 27 & 9 & 20 & 27 & 16 & 12 & 23 & 19 & 12 & \begin{tabular}{|l|}
16 \\
\end{tabular} & 19 & 27 & 31 & 14 & 17 & 11 \\
\hline
\end{tabular}

Table 6: Factor rankings 
The attitude of the teacher has is also regarded as important:

'A negative attitude from the instructor can affect the whole educational process even if he is good at his job. It is essential to motivate the instructors to show a positive attitude towards the eLearning system' (K1)

\section{Student characteristics}

The next most important category is student characteristics. There is a lower level of consensus regarding the relative importance of factors within the student characteristics category. Nevertheless, knowledge with computer systems is regarded as relatively important by most participants. Comments on this centred on the need to understand how the systems work:

'If the student doesn't have the minimum required level of technological knowledge they can't learn through the eLearning system' (K2)

'To be able to use the eLearning systems, the student must have a minimal knowledge of computer systems' (M1).

'The better the student's computer knowledge, the faster he will learn to use the eLearning system' (Q2)

However, those giving a lower ranking to 'Knowledge of computer systems' suggested that eLearning systems were easy to use and therefore students did not need knowledge about the technology:

'eLearning systems are easy to use so basic knowledge should be enough to be able to use the system' (K3).

Student attitudes towards the eLearning system, including their level of motivation and commitment, were also seen as important. For example, commitment was seen as affecting the extent of student learning:

'It is important as it reflects how much the student learns...If students have a negative attitude towards eLearning they will never be able to use it and learn from it' (K3)

Although, it was also acknowledged that:

'The instructor and school management can force the students to be more committed to eLearning through the regulations'. 
Turning to demographics, interviewees vary significantly in the extent to which they regard these as important:

'I think the levels of academic program followed by the age of the student are the most important factors' (K2)

'The younger the students start to use the eLearning system, the better'. (K3)

I don't think these demographic characteristics actually affect the educational gains of the students or the success of the eLearning system'

\section{Learning environment}

Ranked third overall, was the learning environment; in this category, Technical infrastructure was considered most important, being ranked 1 or 2 by six interviewees while the seventh interviewee ranked it 3. Q1 refers to the technical infrastructure as:

'The corner stone for the successful usage of LMS'

And, Q2 suggested that:

'The lack of suitable technologies can lead to lack of usability of the systems'

Related to the technical infrastructure is the Learning Management System (LMS), which was also ranked relatively highly, with five interviewees ranking it either 1 or 2 . Comments include:

It is very important to have an efficient LMS as it helps the acceptance and the success of the eLearning system' (M1)

'It should be carefully chosen to suit the needs of the students and the learning materials'. (M2)

Access and Navigation was placed in third place among the four learning environment-based factors, largely as a result of lack of consensus on the part of the interviewees. The two interviewees, who ranked access and navigation as ' 1 ', associated it with use and usability:

'This is essential to increase the usage and enhance the eLearning system usability' (M1)

'There should be easy access to learning material so the eLearning system is successfully used' (Q1)

M2 suggests, however, that: 
'Access and navigation is important for easy use of information, however, with good training, this importance can fade away' (M2)

Instructional Design

Instructional design, overall, was ranked as relatively unimportant, however, it embraces some important factors relating to the design of learning. Clarification of learning objectives is the most important factor. Reasons given for this are:

'The most important factor is the clarity of the objectives as based on that the outcomes of the learning process is decided. Objectives should be clear and measurable' (Q2)

'Clarity of objectives... without it, the educational process can lose track' (M1)

On the other hand, K3, who place this factor last, did so because:

'I don't think it is an independent factor; it is associated with the content quality factor'.

Content quality also received a high ranking. The interviewee who ranked it as most important explained that:

'The content should be of high quality and interesting for the students so it motivates them to learn' (M2).

Comments from other interviewees include:

'Greater variety of content will allow better learning' (Q2).

'It is the basis for a good educational system and I believe it helps the success of the eLearning system' (M1).

In the third place were learning strategies. The interviewee who ranked it first justified their ranking thus:

'It is important to have clear strategies as it will help the instructor and the students to follow them' (K3).

Even the interviewee who placed it in fourth place, still felt that it was important:

'It is an essential part of any educational system. Having different strategies can help the management to design a suitable learning for different types of students' (M1). 
Support

The lowest ranked category in this research is Support. Within Support, training is the most important factor, followed by communication tools and lastly help desk availability. Training was ranked ' 1 ' by four interviewees, ' 2 ' by two interviewees, and ' 3 ' by one interviewee. M2 suggested:

'Training helps the student to explore the possibilities that can get from using the system' (M2)

Perhaps surprisingly, help desk availability features as the lowest ranking factor in the lowest ranking category. One interviewee felt that the helpdesk was:

'Important for both instructors and students to allow faster learning' (K3)

But, those who regarded it as least important suggested that a help desk is unimportant because it is only a safety net when training has failed or is insufficient:

In cases where the training and communications fails, the help desk should be able to help the users to finish their tasks' (Q1)

'The help desk offers only temporary assistance with problem and is not as important as training and communication tools' (M2).

\section{Discussion and conclusion}

This research was motivated by the limited amount of prior research on the current status of eLearning in Saudi academic institutions, despite the significant investments that have been made in this area in recent years. This research aims to explore the factors that impact on the implementation and acceptance of eLearning systems in Saudi Arabia and conduct a comparison between these CSFs and similar CSFs discussed in the relevant literature. Using interviews with e-Learning experts in three universities in Saudi Arabia, followed by thematic analysis, the research identified and explored five categories of eLearning CSFs: student characteristics, instructor characteristics, learning environment, instructional design, and support. Instructor characteristics emerge as the most influential category on the overall success of the eLearning systems, followed by student characteristics, learning environment, instructional design, and support, respectively. The factors within each category and their relative importance were also explored (Figure 1). 
Since the development of the interview schedule for this research was informed by previous research, it is not surprising to find some overlap between the categories of critical success factors in this research and previous research. However, the similarity is also reflected in the relative importance of CSF categories. For example, instructor characteristics was found to be the most important category of eLearning CSFs by Selim (2007), whilst student characteristics was identified to be very important category by Bhuasiri et al. (2012) and Baylor and Ritchie (2002). In addition, with regard to specific factors, knowledge of computers/technology has been identified as the most impactful factor for both the students and the instructor characteristics categories, echoing the findings of earlier researchers (Bhuasiri et al., 2012; Soong et al., 2001), and in the learning environment category, technical infrastructure was the most important, consistent with Selim (2007). Clarity of learning objectives and training were the most important CSFs in the instructional design and support related categories respectively, consistent with one of the prior studies conducted in Saudi Arabia (AlHomod and AlShafi,2013). 


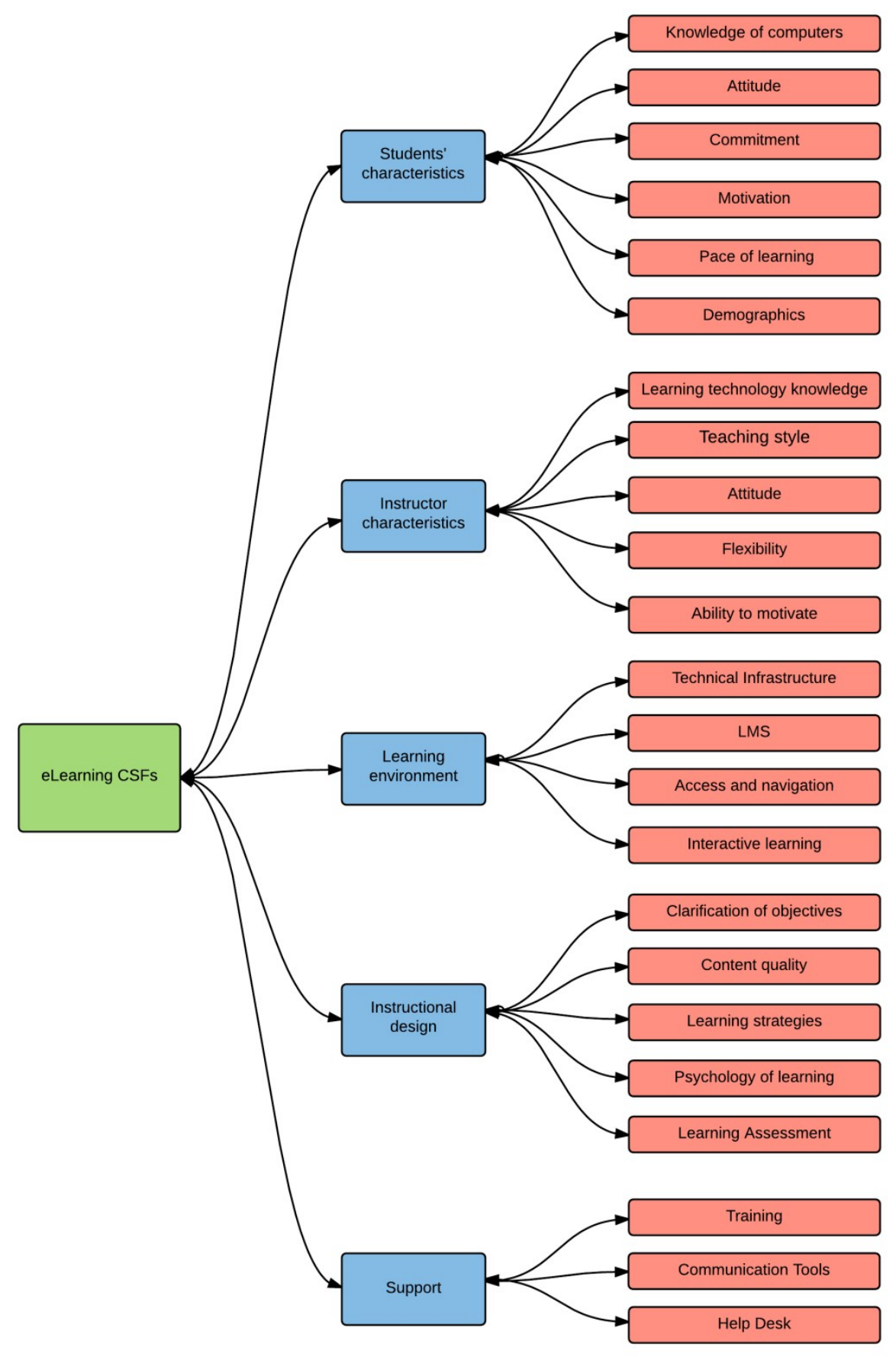

Figure 1: eLearning CSFs in Saudi universities ordered by their importance 21 
On the other hand, this research advances on prior work by offering a more comprehensive and current review of the important CSFs for the acceptance of eLearning. Figure 1 presents a more comprehensive list of critical success factors than most other studies. Furthermore, it specifically advances on previous research conducted in Saudi Arabia, by extending the focus beyond technical issues (Allomod and Alshafi, 2012; AlTameem, 2013) and offering a rather different set of CSF categories, to those proposed by Fryan and Stergioulas (2012), and by ranking those categories, and CSF's within categories. Furthermore, is complements the perspective offered by Al-Asmari and Khan (2014), who focus on obstacles.

This research makes a useful contribution to understanding the factors that might affect the adoption and success of eLearning, and can be used to inform government and university policymaking regarding investment in eLearning. The study has one major limitation, and that is its focus on the perspectives of eLearning experts. Further studies could usefully explore and compare the groups of different groups, such as academic staff and students. In particular, these studies, and further studies involving gathering the perceptions of eLearning experts in a wider range of universities, including, for instance those with recent implementations of eLearning would benefit from the categorization of factors and their components proposed in Figure 1. In addition, there is considerable scope for further studies into the factors that influence the adoption and continued use of eLearning in different systems, learning and cultural contexts, including further development of understanding of both the benefits and disadvantages of eLearning approaches.

Practitioners can benefit from this study by extending their understanding of the factors that affect the success of eLearning in their university. Other studies have identified a range of recommendations for e-Learning practice. Accordingly, based on the rankings developed in this study, we propose that the four most important considerations are:

a. Given the importance of both student and instructor' knowledge of technology, training for all the involved parties on how to use and benefit from the eLearning system should be an essential part of the eLearning system development and operational planning.

b. Positive attitudes are also important. Specifically for students, it is important for decision makers to consider this factor through studying the learning and student culture. 
c. Another key success factor is the technical infrastructure, which includes the LMS, networking, communication tools and other facilities. Decision makers need to ensure the quality and accessibility of this infrastructure, by committing a sufficient level of financial and human resources.

d. Instructional design is also important, especially with regard to learning objectives. Decision makers should extend their focus beyond the technology to the instructional design and in particular to clear definition of learning objectives.

\section{References}

Abalhassan, K.M. (2007), "Higher Education in Saudi Arabia". Center for Publication \& Translation. Riyadh: Ministry of Higher Education.

Abdel-Gawad, T. and Woollard, J., 2015. Critical success factors for implementing classless eLearning systems in the Egyptian higher education. Instructional Technology, Vol.12, No. 4, p.2940.

Al-Asmari, A.M., \& Khan, M.S.R. (2014), "E-Learning in Saido Arabia; Past, present and future. Near and Middle Eastern Journal of Research in Education, Vol. 2, pp.1-11. Available at: http://dx.doi.org/10.5339/nmejre.2014.2.

Al-Dosari, H. (2011). "Faculty members and students perceptions of ELearning in the English department: A project evaluation”. Journal of Social Sciences, Vol. 7, No. 3, pp. 391-407 Alhomod, S., \& Shafi, M. M. (2013), "Success Factors of ELearning Projects: A Technical Perspective". Turkish Online Journal of Educational Technology, Vol. 12, No.2, pp. 247-253.

AlTameem, A. (2013), "What drives successful ELearning? An empirical investigation of the key technical issues in Saudi Arabian Universities". Journal of Theoretical and Applied Information Technology, Vol. 53, No 1, pp.63-70

Alwalidi, A., \& Lefrere, P. (2010), "Making eLearning invisible: Experience at King Khalid University, Saudi Arabia”. Educational Technology, Vol 50, No.3, pp. 1-6.

Amberg, Fischl and Wiener (2005), "Background of Critical Success Factors Research". Working paper No. 2. Friedrich-Alexander-Universität Erlangen-Nürnberg available at: https://static.aminer.org/pdf/PDF/000/245/894/critical_success_factors_csfs_and the growth of it in.pdf (accessed 30/12/2015) 
Bacsich, P., Bastiaens, T., Frank Bristow, S., Op de Beeck, I., Reynolds, S., \& Schreurs, B. (2009), "Reviewing the Virtual Campus Phenomenon. The Rise of Large-scale eLearning Initiatives Worldwide", EuroPACE ivzw, Leuven

Baylor, A. L., \& Ritchie, D. (2002), "What factors facilitate teacher skill, teacher morale, and perceived student learning in technology-using classrooms?". Computers \& Education, Vol. 39 No. 4, pp. 395-414.

Bhuasiri, W., Xaymoungkhoun, O., Zo, H., Rho, J. J., \& Ciganek, A. P. (2012), “Critical success factors for eLearning in developing countries: A comparative analysis between ICT experts and faculty". Computers \& Education, Vol. 58 No. 2, pp. 843-855.

Caporarello, L., \& Sarchioni, G. (2014), “ELearning: the recipe for success”. Journal of eLearning and Knowledge Society, Vol. 10, No. 1. pp. 117-128

Chantanarungpak, K., \& Songkla, J. N. (2010), "Development of success indicators of eLearning system for higher education institutions in Thailand”. Ph.D. Thesis, Bangkok: Chulalongkorn University

Colley, A. M., Gale, M. T., \& Harris, T. A. (1994), "Effects of gender role identity and experience on computer attitude components". Journal of Educational Computing Research, Vol. 10, No. 2, pp. 129-137.

Collis, B. (1995). The evolution of educational software productivity. In D. Ely \& B. Minor (eds.), Educational media and technology yearbook. Volume 21 (pp. 76-97). Englewood, CO: Libraries Unlimited.

Daniel, D. R. (1961), “Management information crisis”. Harvard Business Review, Vol. 39, No. 5, pp. 111-121.

Fryan, L. B., \& Stergioulas, L. (2013). An Investigation into Best Practices for ELearning Implementation in Higher Education. In EC-TEL Doctoral Consortium, pp. 20-29. available at: http://ceur-ws.org/Vol-1093/paper4.pdf (accessed 30/12/2015)

Gable, G. G., Sedera, D., \& Chan, T. (2008), "Re-conceptualizing information system success: The IS-impact measurement model". Journal of the Association for Information Systems, Vol. 9, No. 7, pp.1-52

Greene, F., Loughridge, B., \& Wilson, T. (1996) “The Management information needs of academic heads of department in universities: a critical success factors approach". Journal of Information 
Science, Vol. 19, .No. 6, pp. 425-437.

Guri-Rosenblit, S. (2005). 'Distance education' and 'eLearning': Not the same thing” Higher education, Vol. 49, No. 4, pp. 467-493.

Haynes, R.M., Pouraghabagher, R. and Seu, A. (1997) "Interactive distance education alliance (IDEA): collaborative model delivers on demand". Technological Horizons in Education. Vol. 24, No. 8, pp.60-63.

Harasim, L. (2006). “A history of eLearning: Shift happened”, The International Handbook of Virtual Learning Environments, (pp. 59-94): Springer.

Hassanzadeh, A., Kanaani, F., \& Elahi, S. (2012). "A model for measuring eLearning systems success in universities”. Expert Systems with Applications, Vol. 39, No. 12, pp. 10959-10966.

Huddlestone, J., \& Pike, J. (2008). "Seven key decision factors for selecting eLearning”. Cognition, Technology \& Work, Vol. 10, No. 3, pp. 237-247.

Le Blanc, A., \& Wands, M. (2001). "Critical success factors: eLearning solutions cappuccino”. The Official E-Newsletter of the Change and Learning Practice, available at: http://www.internettime.com/itimegroup/crit_capp.htm (accessed 30/12/2015)

Lee, W. W., Owens, D. L., \& Benson, A. D. (2002). "Design considerations for web-based learning systems". Advances in Developing Human Resources, Vol. 4, No. 4, pp. 405-423.

Leidner, D. E., \& Jarvenpaa, S. L. (1993). The information age confronts education: Case studies on electronic classrooms. Information Systems Research, Vol. 4, No. 1, pp. 24-54

Masrom, M., Zainon, O., \& Rahiman, R. (2008). ELearning critical success factors: institutional and technological aspects. ELearning Issues in Malaysian Higher Education, pp. 49-63.

McPherson, M., \& Baptista Nunes, M. (2006). "Organisational issues for eLearning: Critical success factors as identified by HE practitioners". International Journal of Educational Management, Vol. 20, No. 7, pp. 542-558.

McIntyre, D. R., \& Wolff, F. G. (1998). “An experiment with WWW interactive learning in university education”. Computers \& Education, Vol. 31, No. 3, pp. 255-264.

Menchaca, M. P., \& Bekele, T. A. (2008), "Learner and instructor identified success factors in distance education". Distance education, Vol. 29, No.3, pp. 231-252.

Moore, M. and Kearsley, G., (2005) “Distance Education: A Systems View”, Thomson Wadsworth. 
Mosakhani, M., \& Jamporazmey, M. (2010). "Introduce critical success factors (CSFs) of elearning for evaluating eLearning implementation success". Educational and Information Technology (ICEIT), 2010 International Conference on, Vol. 1, pp. V1-224, IEEE.

Mylonas, P., Tzouveli, P. and Kollias, S., (2004), Towards a personalized e-Learning scheme for teachers. In Advanced Learning Technologies, 2004. Proceedings. IEEE International Conference on (pp. 560-564). IEEE.

National Centre of ELearning and Distance Learning (2015) Available at: http://he.moe.gov.sa/en/aboutus/institutions/Pages/Distance-Education.aspx _Accessed December, 2015)

Pawlowski, J. M., \& Bick, M. (2006). "Managing \& re-using didactical expertise: The Didactical Object Mode". Journal of Educational Technology \& Society, Vol. , No. 1, pp. 84-96.

Puri, G. (2012). "Critical success Factors in eLearning-An empirical study. International Journal of Multidisciplinary Research, Vol. 2, No. 1, pp.149-161.

Rockart, J. F. (1979). “Critical success factors”. Harvard Business Review, Vol. 57, No.2, pp. 8191.

Salmeron, J. L. (2009). "Augmented fuzzy cognitive maps for modelling LMS critical success factors". Knowledge-based systems, Vol. 22, No. 4, pp. 275-278.

Sangrà, A., Vlachopoulos, D. and Cabrera, N. (2012) "Building an inclusive definition of eLearning: An approach to the conceptual framework", The International Review of Research in Open and Distance Learning, vol. 13, no. 2, pp. 146-159.

Schreurs, B., Bascich, P., Bristow, S., Op De Beeck, I., \& Reynolds, S. (2009). Reviewing the Virtual Campus Phenomenon. The Rise of Large-Scale eLearning Initiatives Worldwide. EuroPACE ivzw, Leuven.

Selim, H. M. (2007). "Critical success factors for eLearning acceptance: Confirmatory factor models". Computers \& Education, Vo. 49, No. 2, pp. 396-413

Sloman, M. (2002). The ELearning Revolution: How Technology Is Driving a New Training Paradigm. AMACOM, New York

Siritongthaworn, S., Krairit, D., Dimmitt, N.J., and Paul, H. (2006) "The study of eLearning technology implementation: A preliminary investigation of universities in Thailand," Education and Information Technologies. Vol. 11, No. 2, pp. 137-160. 
Song, L., Singleton, E. S., Hill, J. R., \& Koh, M. H. (2004). "Improving online learning: Student perceptions of useful and challenging characteristics". The Internet and Higher Education, Vol. 7, No. 1, pp. 59-70

Soong, M. B., Chan, H. C., Chua, B. C., \& Loh, K. F. (2001). "Critical success factors for on-line course resources". Computers \& Education, Vol. 36, No. 2, pp. 101-120

Volery, T., \& Lord, D. (2000). "Critical success factors in online education”. International Journal of Educational Management, Vol. 14, No. 5, pp. 216-223.

Wang, Y. S., Wang, H. Y., \& Shee, D. Y. (2007). "Measuring eLearning systems success in an organizational context: Scale development and validation". Computers in Human Behavior, Vol. 23, No. 4, pp.1792-1808.

Webster, J., \& Hackley, P. (1997). "Teaching effectiveness in technology-mediated distance learning”. Academy of Management Journal, Vol. 40, No. 6, pp.1282-1309. 